\title{
Isotope evidence for the use of marine resources in the Eastern Iberian Mesolithic
}

\author{
Domingo C. Salazar-García a,b,c,*, J. Emili Aura ${ }^{\text {b }}$, Carme R. Olària ${ }^{\mathrm{d}}$, Sahra Talamo ${ }^{\mathrm{a}}$, \\ Juan V. Morales ${ }^{\text {b }}$, Michael P. Richards ${ }^{\text {a,e, }}$, \\ ${ }^{a}$ Department of Human Evolution, Max-Planck Institute for Evolutionary Anthropology, Leipzig, Germany \\ ${ }^{\mathrm{b}}$ Departament de Prehistòria i Arqueologia, Universitat de València, Valencia, Spain \\ ${ }^{c}$ Research Group on Plant Foods in Hominin Dietary Ecology, Max-Planck Institute for Evolutionary Anthropology, Leipzig, Germany \\ ${ }^{\mathrm{d}}$ Departament de Historia, Geografia y Arte, Universitat Jaume I, Castellón, Spain \\ e Department of Anthropology, University of British Columbia, Vancouver, Canada \\ ${ }^{\mathrm{f}}$ Department of Archaeology, University of Durham, Durham, UK
}

\section{A R T I C L E I N F O}

\section{Article history:}

Received 16 July 2013

Received in revised form

2 November 2013

Accepted 5 November 2013

\section{Keywords:}

Stable isotopes

Palaeodiet

Mesolithic

Mediterranean Iberia

\begin{abstract}
A B S T R A C T
There are relatively few coastal Mesolithic sites in the Iberian Mediterranean region, probably due to a number of factors including sea level changes and the disappearance of sites due to agriculture and urbanisation. However, recent excavations have uncovered inland sites that have marine faunal remains (i.e. molluscs and fish) and lithics from the coastal area, which both indicate interactions between the coast and the upland valleys. These inland sites are located at a distance of $30-50 \mathrm{~km}$ from today's coastline and are at altitudes higher than $1000 \mathrm{~m}$. We report on additional information on the links between the coast and these inland sites through the use of dietary isotope analysis (carbon and nitrogen stable isotope analysis) of collagen extracted from human and faunal remains at the sites of Coves de Santa Maira, Penya del Comptador and Cingle del Mas Nou. The results indicate that Mesolithic diet in this region was largely based on $C_{3}$ terrestrial resources, but there was measurable evidence of low-level consumption of marine resources at both coastal and inland sites.
\end{abstract}

(c) 2013 Elsevier Ltd. All rights reserved.

\section{Introduction}

The central Iberian Mediterranean region is centered around the coastal area of Valencia. To the north, west and south of this alluvial plain are the Iberic and Betic mountain ranges, with layered valleys and mountain peaks that reach up to $1500 \mathrm{~m}$ in altitude. This region has a long tradition of research on the Epipalaeolithic and Mesolithic periods (Fortea, 1973; Martí et al., 2009) with recent published syntheses on environmental (Badal and Carrión, 2001), funerary (Aura, 2009; Olária et al., 2010; García Puchol et al., 2012), palaeoeconomy (Aura et al., 2005, 2009) and chronological (Aura et al., 2011) questions.

The archaeological regional sequence of the last foragers in this region is organized into two major periods (Aura, 2001; Aura et al., 2011): the Epi-Magdalenian (13,200-10,500 calBP) and the Mesolithic (10,100-7600 calBP). The Epi-Magdalenian has a tradition of

\footnotetext{
* Corresponding author. Department of Human Evolution, Max-Planck Institute for Evolutionary Anthropology, Deutscher Platz 6, 04103 Leipzig, Germany.

E-mail addresses: domingo_carlos@eva.mpg.de, domingocarlos.salazar@uv.es (D.C. Salazar-García).
}

blade lithic production (end-scrapers, retouched blades, notches, etc.) with bladelet projectile components that incorporate microliths from the Younger Dryas (12,900-11,500 calBP) onwards (small triangles and segments, double points, Sauveterre points, etc.), and a few bone and antler points. The Mesolithic is divided into two stages: an initial Mesolithic with notches and denticulates, characterized by flake production and knapping of local raw materials (Alday, 2006), and a later Geometric Mesolithic with laminar production used as support for the elaboration of geometric tools (triangles, trapezes, segments). The sites studied here correspond to both Mesolithic stages (Aura, 2009).

The palaeoeconomy data shows the use of resources from the coastal, inner valley, and middle-mountain areas. The most common mammal species found at Mesolithic sites are Cervus elaphus and Capra pyrenaica. Sus scrofa, Rupicapra rupicapra, and Capreolus capreolus also present in lower frequencies and Equus sp. and Bos sp. appear rarely. The most common carnivores are Vulpes vulpes, Felis sylvestris, Lynx pardina and Canis lupus. Smallgame (Oryctolagus cuniculus and birds) are abundant but appear in lower frequencies than during the Late Magdalenian (Aura et al., 2009). 
The archaeological evidence points to a regional settlement model that has links between coastal and high altitude inland sites. Data come exclusively from rock shelters and caves, since there is a lack of knowledge about open-air sites in the region for this period. In this context, and acknowledging the presence of marine remains at the inland site of Santa Maira (Aura et al., 2009), direct dietary evidence obtained from carbon and nitrogen stable isotope analysis would help to establish if there was the regular consumption of marine resources at these inland sites, and if so, help us better understand the regional settlement, contact between inland and coastal sites, and the use of the landscape in the Mesolithic of this area.

\section{The study sites}

\subsection{Coves de Santa Maira}

The site of Coves de Santa Maira is a cave located in the Valencian town of Castell de Castells (Fig. 1 and Fig. 2a) and was discovered during the 1980 s. It occupies a rocky promontory $600 \mathrm{~m}$

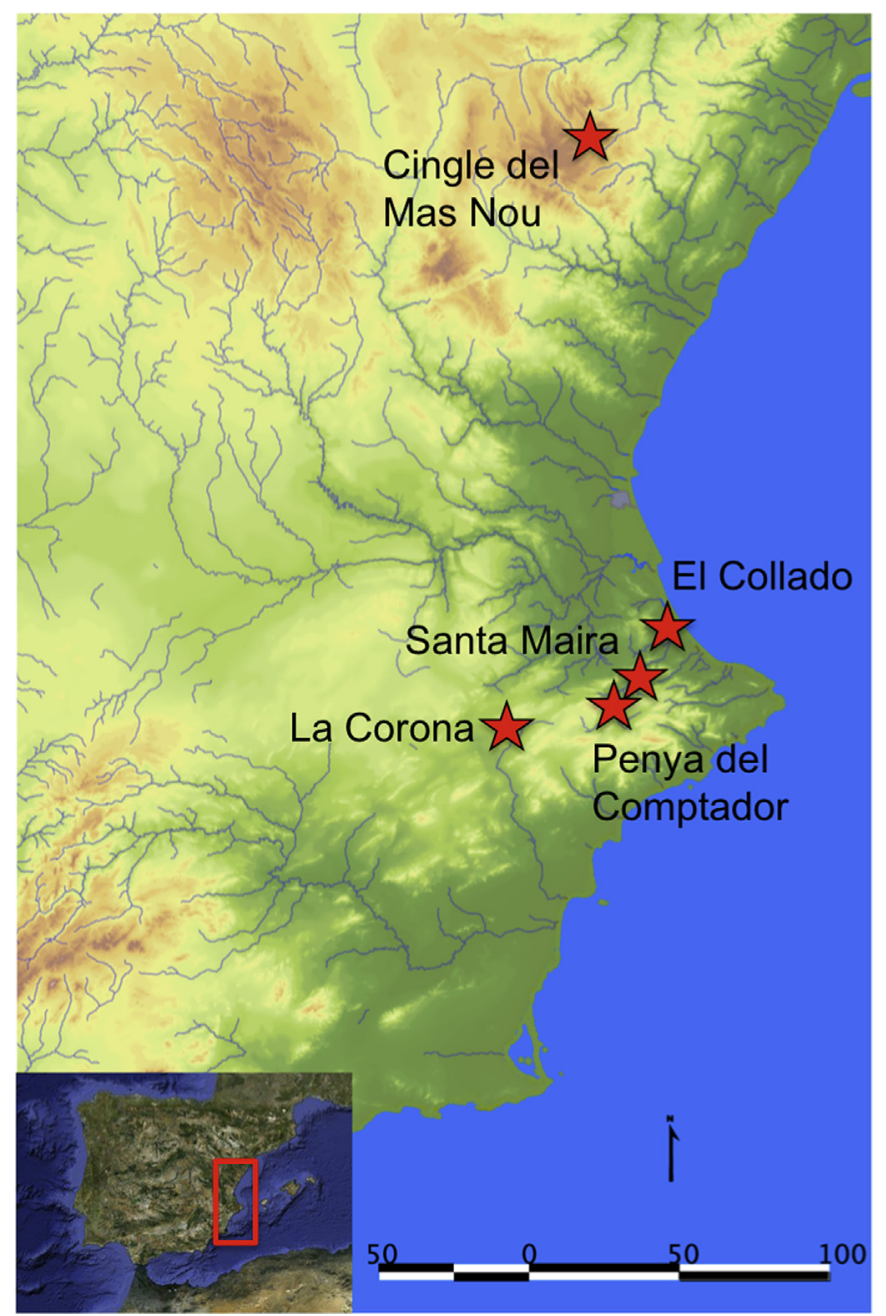

Fig. 1. Map of Mesolithic sites in Eastern Iberia. Current distance to the coast in a straight line from each of the sites is: $5 \mathrm{~km}$ for El Collado, $25 \mathrm{~km}$ for Santa Maira, $27 \mathrm{~km}$ for Penya del Comptador, $42 \mathrm{~km}$ for Cingle del Mas Nou, and $45 \mathrm{~km}$ for La Corona. Estimated distance between each of the sites to the coast in a straight line during 10,936-8471 cal BP is of $21 \mathrm{~km}$ for El Collado, $30 \mathrm{~km}$ for Penya del Comptador, $33 \mathrm{~km}$ for Santa Maira, $49 \mathrm{~km}$ for La Corona, and $53 \mathrm{~km}$ for Cingle del Mas Nou (estimations based on Jordá et al., 2011). above sea level, close to the river Gorgos in the Barranc de Famorca, in an area known for its Neolithic rock art shelters (Hernández et al., 1988). Five units have been described at the west hall trench (Aura et al., 2008): Unit 5 (Late Magdalenian), Unit 4 (Epimagdalenian and Epipalaeolithic with Sauveterrian elements), Unit 3 (Mesolithic), Unit 2 (Neolithic), Unit 1 (more recent periods). Radiocarbon dates for the Mesolithic sequence can be found in Table 1.

Although excavation and analysis is still ongoing, the initial anthropological study (De Miguel, 2009) of the human remains from the Mesolithic levels gives an MNI (Minimum Number of Individuals) of three: 2 adults and 1 child (Table 2). Palaeoenvironmental reconstruction shows an expansion of the Holocene forest (Aura et al., 2005, 2006; Badal and Carrión, 2001). Geoarchaeological and micromorphology studies show temperate conditions during the Mesolithic (Aura et al., 2006; Verdasco, 1999). Lithic and bone industry studies show successive episodes of Mesolithic occupations in relation to the exploitation of the middlemountain region (Aura, 2001; Aura et al., 2006; Miret, 2007). Faunal and palaeoeconomical research suggests that the site was used for specialised goat hunting, although the number of forest animal remains at the site (Cervus elaphus, Rupicapra rupicapra and Sus scropha) increased through the Holocene. The use of small-game (rabbits, hedgehogs, foxes), plants and marine resources (fish, molluscs) has also been documented (Aura et al., 2005, 2006, 2009; Pérez-Ripoll, 1992).

\subsection{Penya del Comptador}

Penya del Comptador is a rock shelter located close to the Valencian town of Alcoi, at $850 \mathrm{~m}$ above sea level (Figs. 1 and 2b). This site has only a sparse archaeological record, although two different time periods can be identified: an Early Neolithic occupation with cardial pottery fragments in the surface, and a Mesolithic burial at the bottom with a few flakes, blades, cores, and retouched tools (backed bladelets, endscrapers, notches). Its archaeological materials come from a deposit that has been completely destroyed except for one part attached to the wall (Aura et al., 2006). The most important findings are the adult human remains (Table 3), which have been dated to the Mesolithic (Aura et al., 2006; De Miguel, 2009). As can be seen in Table 1, the dates are quite similar to the ones from Coves de Santa Maira. Both sites are very close to each other, only $20 \mathrm{~km}$ apart.

\subsection{Cingle del Mas Nou}

Cingle del Mas Nou is an open-air site close to a rock shelter situated in the town of Ares del Maestre, in the northern part of the Valencian Country. It is on the southern side of Serra d'En Seller, close to the valleys of Cirerals and Molero, at $940 \mathrm{~m}$ above sea level (Figs. 1 and 2c). The site was discovered in 1975, and excavations ran from 1986 to 1999 . The stratigraphic sequence of the site is divided into five levels, grouped in two occupation phases: Levels I and II are associated with the Early Neolithic, Levels III and IV to the Geometric Mesolithic, and Level 5 is sterile (Olària, 2007). The analysis of the excavated remains is ongoing. Nine human individuals dating to the Mesolithic have been described (Table 4): 2 adults and 7 children of different ages (Olària et al., 2010).

\section{Stable isotopes and palaeodietary reconstruction}

Carbon and nitrogen stable isotope analysis is a commonly used method for the reconstruction of past human and animal diets. This technique is based on the principle that the isotopic composition of the food eaten by both animals and humans is recorded on their 


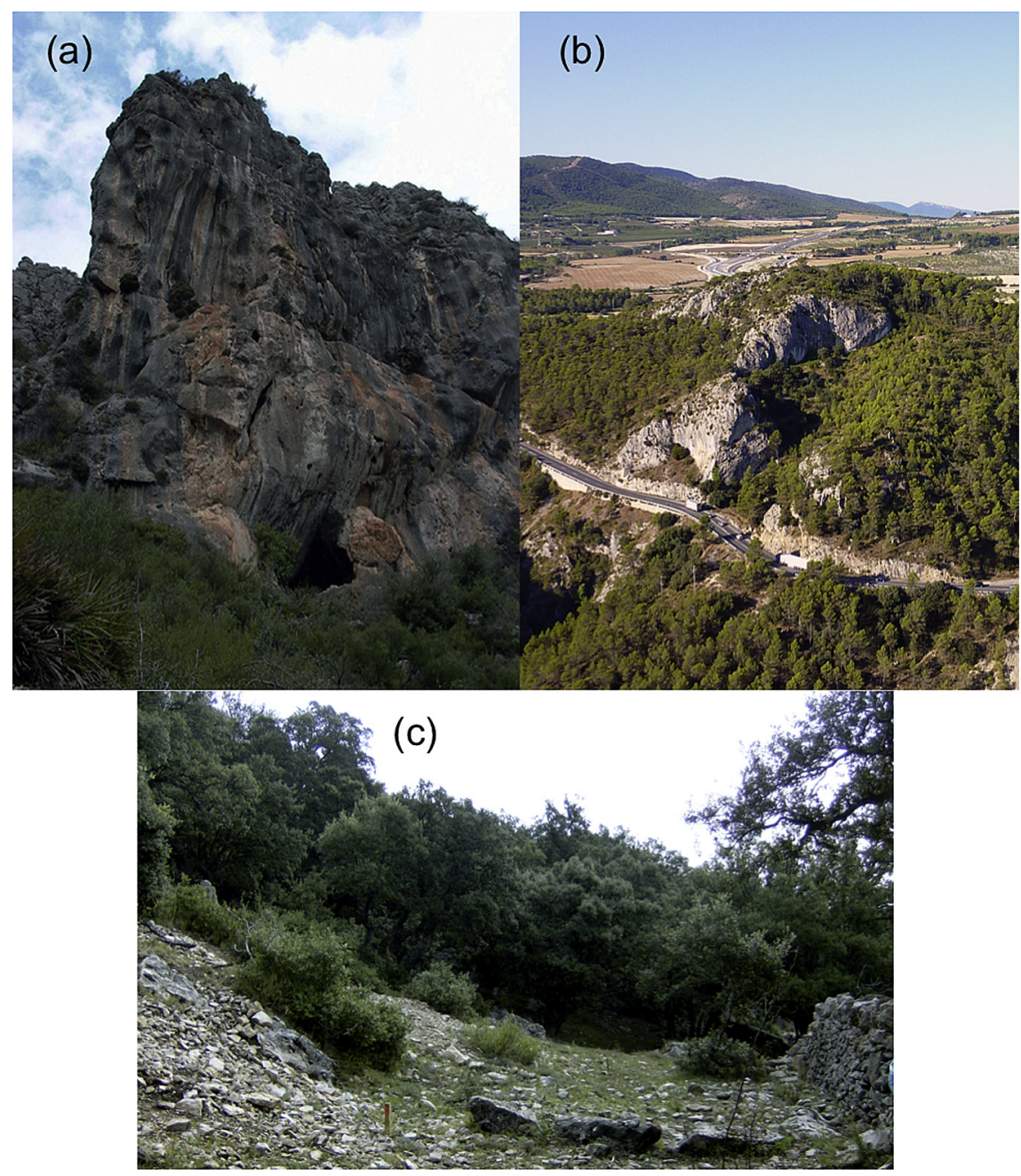

Fig. 2. Photographs of the sites of (a) Santa Maira, (b) Penya del Comptador, and (c) Cingle del Mas Nou.

body tissues after a predictable isotope fractionation (Schoeller, 1999, and see reviews by Ambrose, 1993; Katzenberg, 2000; LeeThorp, 2008; Sealy, 2001).

The $\delta^{13} \mathrm{C}$ stable isotope ratio distinguishes the consumption of terrestrial $\left({ }^{13} \mathrm{C}\right.$ depleted) and marine $\left({ }^{13} \mathrm{C}\right.$ enriched $)$ foods (Chisholm et al., 1982). It helps as well to define the input on the diet of $C_{3}\left({ }^{13} \mathrm{C}\right.$ depleted) from $C_{4}$ resources $\left({ }^{13} \mathrm{C}\right.$ enriched) (Van der Merwe and Vogel, 1978). Since there are no edible $C_{4}$ plants reported in Europe during the Mesolithic time period (Sage et al., 1999), the main use of carbon isotopes is for estimating the consumption of marine protein. In an ecosystem devoid of $\mathrm{C}_{4}$ plants, a $\delta^{13} \mathrm{C}$ value around $-20 \%$ would indicate a total terrestrial diet, and one about -10 to $-12 \%$ would indicate that almost all ingested protein was marine. The $\delta^{15} \mathrm{~N}$ stable isotope ratio increases by $3-$ $5 \%$ up the food-chain with each trophic level, meaning that the consumer has higher values than the consumed protein (De Niro and Epstein, 1981; Schoeninger and De Niro, 1984). This makes nitrogen stable isotopes useful for detecting the presence of high trophic level marine and freshwater foods on the diet (Schoeninger et al., 1983). However, the distinction of animal-rich diets from plant-rich diets using $\delta^{15} \mathrm{~N}$ values (Minagawa and Wada, 1984) is less straightforward than previously thought (i.e. Hedges and Reynard, 2007; Warinner et al., 2013).

Bone and tooth collagen are the preferred substrate for carbon and nitrogen stable isotope analysis. Quality indicators are used to determine the preservation quality of the extracted collagen (De Niro, 1985; Van Klinken, 1999). Because of slow collagen turnover, collagen stable isotope values reflect an average diet representative of the last 10-15 years of life (Hedges et al., 2007). In addition, they mainly reflect the isotopic signals of the main dietary protein sources rather than that of a diet as a whole, especially for nitrogen (Ambrose and Norr, 1993) since carbon may be derived from other dietary macronutrients like sugars and fats (Howland et al., 2003; Jim et al., 2006).

\section{Material and methods}

\subsection{Radiocarbon dating}

Four human bone samples were selected from the three sites for AMS radiocarbon dating: one from Santa Maira, one from Penya del Comptador, and two from Cingle del Mas Nou (see "New dates" from Table 1). Bone was pre-treated for collagen extraction at the Department of Human Evolution of the Max Planck Institute for Evolutionary Anthropology (Leipzig, Germany) following the method described below. AMS radiocarbon analyses were performed at the Oxford laboratories. Calibration of radiocarbon dates was performed using IntCal09 and OxCal 4.2beta (Bronk Ramsey, 2009; Reimer et al., 2009). 
Table 1

Radiocarbon dates from Coves de Santa Maira, Penya del Comptador and Cingle del Mas Nou.

\begin{tabular}{|c|c|c|c|c|c|c|c|c|c|}
\hline Site & Context & Material & MPI ref. & Lab ref. & $14 C$ age & Err & cal BP $1 \sigma$ & cal BP $2 \sigma$ & Reference \\
\hline Coves de Santa Maira & Mesolithic & Human bone & S-EVA 9051 & OxA-V-2360-26 & 8283 & 37 & 9410-9140 cal BP & $9420-9130 \mathrm{cal} \mathrm{BP}$ & This paper \\
\hline Coves de Santa Maira & Mesolithic & Human bone & - & Beta 244010 & 8690 & 50 & 9690-9550 cal BP & 9890-9540 cal BP & Aura et al., 2011 \\
\hline Penya del Comptador & Mesolithic & Human bone & - & Beta 156025 & 8570 & 40 & 9560-9510 cal BP & $9610-9480 \mathrm{cal} \mathrm{BP}$ & Aura et al., 2006 \\
\hline Penya del Comptador & Mesolithic & Human bone & S-EVA 9097 & OxA-V-2360-30 & 8829 & 38 & $9410-9140 \mathrm{cal}$ BP & $9420-9130 \mathrm{cal} \mathrm{BP}$ & This paper \\
\hline Cingle del Mas Nou & Mesolithic & Human bone & S-EVA 9089 & OxA-V-2360-29 & 6925 & 35 & 7790-7690 cal BP & $7840-7680$ cal BP & This paper \\
\hline Cingle del Mas Nou & Mesolithic & Human bone & S-EVA 9084 & OxA-V-2360-28 & 6897 & 34 & $7760-7680$ cal BP & $7830-7660$ cal BP & This paper \\
\hline Cingle del Mas Nou & Mesolithic & Human bone & - & Beta 170715 & 6820 & 40 & $7680-7610$ cal BP & 7730-7580 calBP & $\begin{array}{l}\text { Olaria et al., 2010; } \\
\text { Olaria 2002-2003 }\end{array}$ \\
\hline Cingle del Mas Nou & Mesolithic & Human bone & - & Beta 170714 & 6910 & 40 & 7790-7680 calBP & $7840-7670 \mathrm{cal} \mathrm{BP}$ & $\begin{array}{l}\text { Olaria et al., 2010; } \\
\text { Olaria 2002-2003 }\end{array}$ \\
\hline
\end{tabular}

Table 2

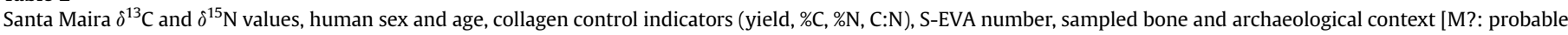
male/F?: probable female].

\begin{tabular}{|c|c|c|c|c|c|c|c|c|c|c|c|}
\hline S-EVA & Species & $\delta^{13} \mathrm{C}(\%)$ & $\delta^{15} \mathrm{~N}(\%)$ & Sex & Age & Yield (\%) & $\% \mathrm{C}$ & $\% \mathrm{~N}$ & $\mathrm{C}: \mathrm{N}$ & Sampled bone & Archaeological context \\
\hline 7691 & Human & -18.1 & 9.4 & Robust (M?) & Adult & 2.3 & 43.7 & 15.8 & 3.2 & Femur diaphysis & $\mathrm{AB} 6 / 1-3.18$ \\
\hline 7692 & Human & -18.0 & 8.8 & Gracile (F?) & Adult & 1.5 & 43.8 & 15.7 & 3.3 & Humerus diaphysis & AA $6 / 1-3.21$ \\
\hline 9051 & Human & -17.8 & 9.9 & Indeterminate & Infantile & 2.8 & 42.7 & 15.4 & 3.3 & Scapula & AA 2/1 -3.6 \\
\hline 7682 & Capra pyrenaica & -19.1 & 3.4 & - & - & 3.0 & 43.6 & 15.6 & 3.3 & Femur diaphysis & AA $5 / 2-3.18$ \\
\hline 7685 & Capra pyrenaica & -19.4 & 4.6 & - & - & 2.6 & 43.9 & 15.7 & 3.3 & Femur diaphysis & AA $5 / 1-3.21$ \\
\hline 7686 & Rupicapra rupicapra & -18.4 & 3.4 & - & - & 1.0 & 43.2 & 15.3 & 3.3 & Radius diaphysis & AA 5/1 -3.21 \\
\hline 7684 & Cervus elaphus & $*$ & * & - & - & 0.3 & 9.2 & 1.0 & 10.7 & Radius diaphysis & $A A 5 / 3-3.19$ \\
\hline 7689 & Cervus elaphus & -19.4 & 4.3 & - & - & 3.0 & 43.6 & 15.7 & 3.2 & Humerus diaphysis & AA $6 / 1-3.21$ \\
\hline 7687 & Sus scrofa & -19.7 & 4.7 & - & - & 1.5 & 43.1 & 15.4 & 3.3 & Scapula & $\mathrm{AB} 6 / 2-3$ \\
\hline 7683 & Oryctolagus cuniculus & -21.4 & 3.8 & - & - & 1.8 & 39.8 & 14.2 & 3.3 & Tibia diaphysis & AA 5/11 - 3.21 \\
\hline 7688 & Oryctolagus cuniculus & -21.6 & 3.3 & - & - & 2.6 & 41.3 & 14.9 & 3.2 & Tibia diaphysis & AA $5 / 2-3.18$ \\
\hline 11203 & Oryctolagus cuniculus & -21.7 & 4.8 & - & - & 1.5 & 41.7 & 14.8 & 3.3 & Radius diaphysis & $\mathrm{AB} 2 / 3-3.6$ \\
\hline 11205 & Oryctolagus cuniculus & -21.4 & 2.7 & - & - & 1.1 & 39.5 & 13.8 & 3.4 & Ulna diaphysis & AB 2/3 -3.6 \\
\hline 14147 & Oryctolagus cuniculus & -20.5 & 2.6 & - & - & 2.7 & 43.0 & 15.5 & 3.2 & Pelvis & AB5/AB6 SC 2-4 -3.17 \\
\hline 14148 & Oryctolagus cuniculus & -20.2 & 2.8 & - & - & 1.9 & 42.4 & 15.2 & 3.3 & Pelvis & $\mathrm{AB} 6 / 2-3.10$ \\
\hline 7681 & Erinaceus europaeus & $*$ & $*$ & - & - & 0.2 & 6.32 & 0.59 & 12.41 & Mandible & $A B 5 / 2-3.18$ \\
\hline 11198 & Lynx silvestris & -19.0 & 6.0 & - & - & 2.1 & 41.6 & 14.7 & 3.3 & Pelvis & AA $2 / 5-3.1$ \\
\hline 11200 & Lynx sp. & -19.3 & 5.8 & - & - & 2.8 & 43.4 & 15.7 & 3.2 & Radius diaphysis & $\begin{array}{l}\text { Level III exp. } \\
(0.80-0.95 \mathrm{~m})\end{array}$ \\
\hline 11201 & Lynx sp. & -19.3 & 7.1 & - & - & 5.1 & 44.4 & 16.1 & 3.2 & Radius diaphysis & $\begin{array}{l}\text { AC Level IV } \\
(2.10-2.25)\end{array}$ \\
\hline 11199 & Vulpes vulpes & -18.9 & 6.6 & - & - & 3.6 & 43.3 & 15.5 & 3.3 & Femur diaphysis & AA $6 / 2-3.18$ \\
\hline 11202 & Vulpes vulpes & -19.4 & 4.4 & - & - & 2.1 & 42.9 & 15.3 & 3.3 & Tibia diaphysis & AB 5/3 -3.3 \\
\hline 11204 & Vulpes vulpes & -18.4 & 6.4 & - & - & 3.8 & 41.7 & 15.0 & 3.3 & Phalanx I diaphysis & AA $6 / 1-3.27$ \\
\hline 17791 & Sparus sp. & -15.2 & 8.6 & - & - & 0.3 & 36.7 & 12.7 & 3.4 & Mandible & $\mathrm{AB} 5 / 3-3.6$ \\
\hline 17793 & Sparus sp. & $*$ & $*$ & - & - & $*$ & $*$ & * & $*$ & Vertebra & AA 5/1 -3.24 \\
\hline 17794 & Sparus sp. & $*$ & * & - & - & $*$ & $*$ & $*$ & * & Vertebra & A 3 NTSM 6/7 I \\
\hline 17795 & Sparus sp. & $*$ & $*$ & - & - & $*$ & $*$ & $*$ & $*$ & Vertebra & A 3 NTSM 6/7 II \\
\hline 17796 & Mugil sp. & -15.2 & 8.5 & - & - & 0.4 & 36.1 & 12.4 & 3.4 & Vertebra & A 4/1 NTSM 12 \\
\hline 17797 & Sparidae sp. & $*$ & $*$ & - & - & $*$ & $*$ & $*$ & $*$ & Vertebra & A 4/1 NTSM 12 \\
\hline 17798 & Sparidae sp. & $*$ & $*$ & - & - & $*$ & $*$ & $*$ & $*$ & Mandible & A 4/1 NTSM 12 \\
\hline 17792 & Sparidae sp. & $*$ & $*$ & - & - & $*$ & $*$ & $*$ & $*$ & Vertebra & AA $5 / 2-3.24$ \\
\hline
\end{tabular}

*In italics the samples that didn't have good collagen quality indicators.

\subsection{Stable isotopic analysis}

Bone samples from 3 humans and 27 animals from Santa Maira, 3 humans and 3 animals from Penya del Comptador, and 9 humans and 36 animals from Cingle del Mas Nou, were sampled. In total, bones from 15 humans and 66 animals, of 13 different species, were sampled.
Prior to analysis, visible contaminants were removed with aluminium oxide powder abrasion. Collagen extraction proceeded following Richards and Hedges (1999), with the addition of an ultrafiltration step (Brown et al., 1988). To summarize, whole bone pieces of ca. $300 \mathrm{mg}$ from each human and animal fragment were demineralized in $0.5 \mathrm{M} \mathrm{HCl}$ solution at $5{ }^{\circ} \mathrm{C}$ over the course of one week, and were then rinsed three times with deionized water

Table 3

Penya del Comptador $\delta^{13} \mathrm{C}$ and $\delta^{15} \mathrm{~N}$ values, human sex and age, collagen control indicators (yield, \%C, \%N, C:N), S-EVA number, sampled bone and archaeological context.

\begin{tabular}{|c|c|c|c|c|c|c|c|c|c|c|c|}
\hline S-EVA & Species & $\delta^{13} \mathrm{C}(\%)$ & $\delta^{15} \mathrm{~N}(\%)$ & Sex & Age & Yield (\%) & $\% \mathrm{C}$ & $\% \mathrm{~N}$ & $\mathrm{C}: \mathrm{N}$ & Sampled bone & Archaeological context \\
\hline 9097 & Human & -18.6 & 7.6 & Indeterminate & Adult & 2.0 & 38.1 & 13.9 & 3.2 & Mandible & S4 Layer VI $n^{\circ} 15$ \\
\hline 9098 & Human & -18.2 & 7.6 & Indeterminate & Adult & 2.5 & 40.2 & 14.9 & 3.2 & Fibula diaphysis & S4 Layer V \\
\hline 9099 & Human & -18.7 & 7.8 & Indeterminate & Adult & 1.1 & 34.1 & 12.2 & 3.3 & Humerus diaphysis & S2 Layer V $n^{\circ} 7$ \\
\hline 9100 & Herbivore & -19.2 & 4.4 & - & - & 1.9 & 40.5 & 14.5 & 3.3 & Long bone diaphysis & S2 Layer V \\
\hline 9101 & Herbivore & -19.6 & 3.6 & - & - & 1.0 & 37.8 & 13.3 & 3.3 & Long bone diaphysis & S Layer IV \\
\hline 9102 & Herbivore & -19.9 & 5.2 & - & - & 1.4 & 38.7 & 14.4 & 3.1 & Long bone diaphysis & $\mathrm{N}$-Test drilling \\
\hline
\end{tabular}


Table 4

Cingle del Mas Nou $\delta^{13} \mathrm{C}$ and $\delta^{15} \mathrm{~N}$ values, human sex and age, collagen control indicators (yield, \%C, \%N, C:N), S-EVA number, sampled bone and archaeological context.

\begin{tabular}{|c|c|c|c|c|c|c|c|c|c|c|c|}
\hline S-EVA & Species & $\delta^{13} \mathrm{C}(\%)$ & $\delta^{15} \mathrm{~N}(\%)$ & Sex & Age & Yield (\%) & $\% C$ & $\% \mathrm{~N}$ & $\mathrm{C}: \mathrm{N}$ & Sampled bone & $\begin{array}{l}\text { Archaeological } \\
\text { context }\end{array}$ \\
\hline 9083 & Human & -18.5 & 8.7 & Male & 40-45 years & 0.9 & 35.9 & 12.8 & 3.3 & Neurocranium & Levels II-III \\
\hline 9084 & Human & -18.4 & 7.9 & Male & 35-39 years & 1.3 & 40.1 & 14.5 & 3.2 & Neurocranium & Levels II-III \\
\hline 9085 & Human & -18.5 & 9.8 & Female & Adult & 2.2 & 42.0 & 15.2 & 3.2 & Neurocranium & Levels II-III \\
\hline 9086 & Human & -18.6 & 8.6 & Male & 15 years & 1.1 & 38.2 & 13.7 & 3.3 & Neurocranium & Levels II-III \\
\hline 9087 & Human & -18.6 & 9.0 & Indeterminate & $6-8$ years & 0.8 & 39.7 & 14.2 & 3.3 & Neurocranium & Levels II-III \\
\hline 9088 & Human & -18.4 & 9.7 & Indeterminate & $2-3$ years & 2.2 & 41.8 & 15.2 & 3.2 & Neurocranium & Levels II-III \\
\hline 9089 & Human & -17.5 & 9.5 & Indeterminate & $3-5$ years & 3.1 & 42.3 & 15.0 & 3.3 & Neurocranium & Levels II-III \\
\hline 9090 & Human & -17.8 & 9.2 & Indeterminate & 6-12 months & 1.7 & 39.4 & 14.1 & 3.3 & Neurocranium & Levels II-III \\
\hline 9091 & Human & -18.3 & 9.8 & Indeterminate & 6 weeks & 4.0 & 41.6 & 15.3 & 3.2 & Neurocranium & Levels II-III \\
\hline 17065 & Sus scrofa & -19.8 & 7.3 & - & - & 0.7 & 34.0 & 11,9 & 3.3 & Tibia diaphysis & Level II \\
\hline 17066 & Sus scrofa & -20.2 & 5.0 & - & - & 0.2 & 38.3 & 13.0 & 3.4 & Tibia diaphysis & Q4 Level I-A \\
\hline 17067 & Sus scrofa & $*$ & $*$ & - & - & $*$ & $*$ & $*$ & $*$ & Femur epiphysis & Q4 Level I-A \\
\hline 17068 & Sus scrofa & $*$ & $*$ & - & - & $*$ & $*$ & $*$ & $*$ & Humerus diaphysis & Q4 Level I-A \\
\hline 17069 & Sus scrofa & -18.4 & 7.0 & - & - & 1.6 & 38.1 & 13.7 & 3.3 & Tibia diaphysis & Level II \\
\hline 17070 & Sus scrofa & -21.0 & 6.9 & - & - & 0.6 & 31.8 & 11.0 & 3.4 & Humerus diaphysis & Level II \\
\hline 17071 & Bos primigenius & -20.0 & 4.1 & - & - & 0.6 & 32.9 & 11.5 & 3.3 & Humerus diaphysis & Level II \\
\hline 17072 & Bos primigenius & -20.1 & 3.8 & - & - & 1.5 & 35.1 & 12.6 & 3.2 & Radius diaphysis & Level II \\
\hline 17073 & Bos primigenius & -19.9 & 4.2 & - & - & 0.7 & 31.4 & 11.0 & 3.3 & Humerus diaphysis & Level II \\
\hline 17074 & Bos primigenius & -19.7 & 4.7 & - & - & 0.4 & 36.5 & 13.1 & 3.3 & Femur diaphysis & Level II \\
\hline 17075 & Capra pyrenaica & -19.2 & 4.0 & - & - & 0.3 & 38.5 & 13.8 & 3.3 & Humerus epiphysis & Level II \\
\hline 17076 & Capra pyrenaica & -19.3 & 4.3 & - & - & 0.3 & 34.7 & 11.8 & 3.4 & Femur epiphysis & Level II \\
\hline 17077 & Capra pyrenaica & -19.2 & 4.2 & - & - & 1.0 & 40.5 & 14.4 & 3.3 & Femur diaphysis & Level II \\
\hline 17078 & Capra pyrenaica & -19.3 & 4.0 & - & - & 0.9 & 35.9 & 13.0 & 3.2 & Femur diaphysis & Level II \\
\hline 17096 & Capra pyrenaica & -19.1 & 3.9 & - & - & 0.2 & 30.2 & 11.0 & 3.2 & Radius diaphysis & Burial $(-120 /-125)$ \\
\hline 17099 & Capra pyrenaica & -18.8 & 4.3 & - & - & 1.8 & 34.3 & 12.3 & 3.3 & Femur diaphysis & Burial $(-120 /-125)$ \\
\hline 17085 & Cervus elaphus & -19.4 & 4.2 & - & - & 0.4 & 32.9 & 11.7 & 3.3 & Humerus diaphysis & Without context \\
\hline 17086 & Cervus elaphus & -19.9 & 3.6 & - & - & 0.4 & 34.1 & 12.3 & 3.2 & Humerus epiphysis & Level I-A \\
\hline 17087 & Cervus elaphus & -19.8 & 3.8 & - & - & 1.5 & 34.2 & 12.4 & 3.2 & Radius diaphysis & Level I-B \\
\hline 17088 & Cervus elaphus & -20.2 & 3.7 & - & - & 0.4 & 30.2 & 10.9 & 3.2 & Tibia diaphysis & Without context \\
\hline 17089 & Cervus elaphus & -19.5 & 4.0 & - & - & 1.6 & 36.3 & 12.7 & 3.3 & Tibia diaphysis & Level I-B \\
\hline 17090 & Cervus elaphus & -19.8 & 3.8 & - & - & 1.2 & 37.6 & 13.4 & 3.3 & Long bone diaphysis & Level I-B \\
\hline 17091 & Cervus elaphus & -19.9 & 3.8 & - & - & 1.3 & 34.8 & 12.5 & 3.2 & Long bone diaphysis & Level I-A \\
\hline 17092 & Cervus elaphus & -19.9 & 3.7 & - & - & 1.2 & 33.6 & 12.1 & 3.2 & Long bone epiphysis & Level I-B \\
\hline 17093 & Cervus elaphus & -19.5 & 3.7 & - & - & 0.7 & 35.0 & 12.6 & 3.3 & Long bone epiphysis & Q4 Level I-A \\
\hline 17094 & Cervus elaphus & -19.7 & 3.8 & - & - & 1.2 & 35.1 & 12.4 & 3.3 & Radius diaphysis & Level III \\
\hline 17095 & Cervus elaphus & -20.0 & 3.5 & - & - & 1.0 & 35.4 & 12.5 & 3.3 & Humerus diaphysis & Level III \\
\hline 17097 & Cervus elaphus & $*$ & $*$ & - & - & $*$ & $*$ & $*$ & $*$ & Tibia diaphysis & Burial $(-120 /-125)$ \\
\hline 17082 & Oryctolagus cuniculus & -21.4 & 3.5 & - & - & 0.5 & 29.6 & 10.3 & 3.4 & Pelvis & Level I \\
\hline 17083 & Oryctolagus cuniculus & -21.3 & 2.7 & - & - & 2.4 & 38.0 & 13.9 & 3.2 & Humerus diaphysis & Level I \\
\hline 17084 & Oryctolagus cuniculus & -20.8 & 2.3 & - & - & 0.3 & 38.6 & 13.2 & 3.4 & Humerus diaphysis & Level I \\
\hline 17081 & Lepus granatensis & -20.6 & 3.1 & - & - & 0.6 & 30.8 & 10.7 & 3.4 & Long bone diaphysis & Level II \\
\hline 17079 & Lynx sylvestris & -17.9 & 11.4 & - & - & 0.2 & 25.3 & 9.1 & 3.3 & Femur diaphysis & Level II \\
\hline 17080 & Lynx sylvestris & $*$ & $*$ & - & - & $*$ & $*$ & $*$ & $*$ & Femur diaphysis & Level II \\
\hline 17100 & Vulpes vulpes? & -17.8 & 7.2 & - & - & 2.2 & 40.0 & 13.9 & 3.4 & Femur diaphysis & Burial $(-120 /-125)$ \\
\hline 17098 & Macro-Mesofauna & $*$ & $*$ & - & - & $*$ & $*$ & $*$ & $*$ & Long bone diaphysis & Burial $(-120 /-125)$ \\
\hline
\end{tabular}

until the $\mathrm{pH}$ became neutral. This was followed by gelatinization over $48 \mathrm{~h}$ at $70{ }^{\circ} \mathrm{C}$, and later by filtering with a $5 \mu \mathrm{m}$ EZEE ${ }^{\odot}$ filter and ultrafiltering with $>30 \mathrm{kDa}$ Amicon $^{\odot}$ ultrafilters. The purified solution was finally frozen and lyophilized before being weighed into tin capsules and loaded into the mass spectrometers.

The carbon and nitrogen isotope ratios in collagen were measured in duplicates using a Delta XP continuous-flow isotope ratio mass spectrometer after being combusted in an elemental analyzer Flash EA 2112 that was interfaced with it (Thermo-Finnighan ${ }^{\odot}$, Bremen, Germany) at the Max-Planck Institute for Evolutionary Anthropology (Leipzig, Germany). Stable carbon isotope ratios were expressed relative to the VPDB scale (Vienna PeeDee Belemnite) and stable nitrogen isotope ratios were measured relative to the AIR scale (atmospheric $\mathrm{N}_{2}$ ), using the delta notation $(\delta)$ in parts per thousand $(\%)$. Repeated analysis of internal and international standards determined an analytical error better than $0.2 \%(1 \sigma)$ for $\delta^{13} \mathrm{C}$ and $\delta^{15} \mathrm{~N}$.

\section{Results}

The stable isotope results for the humans and animals from Santa Maira are presented in Table 2 and Fig. 3. The stable isotope results for the humans and animals from Penya del Comptador are presented in Table 3 and Fig. 4. The stable isotope results for the humans and animals from Cingle del Mas Nou are presented in Table 4 and Fig. 5.

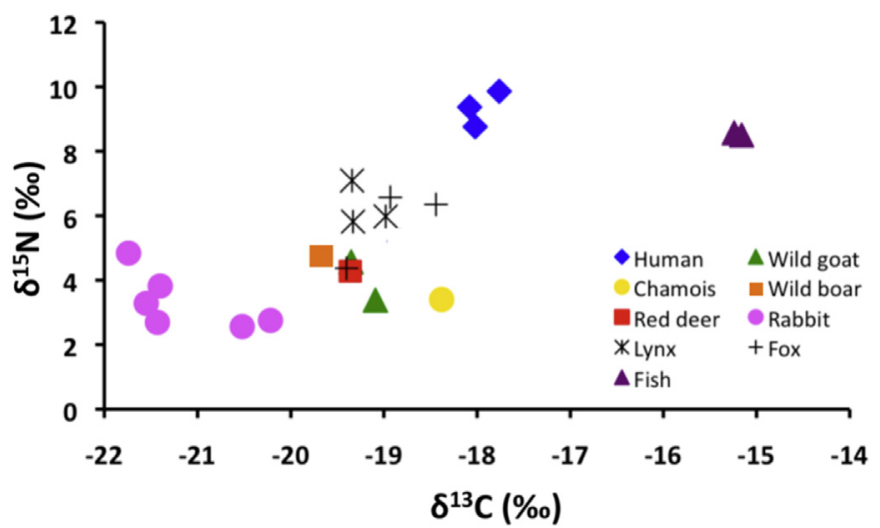

Fig. 3. Plot of human and animal bone collagen $\delta^{13} \mathrm{C}$ and $\delta^{15} \mathrm{~N}$ values from Santa Maira. 


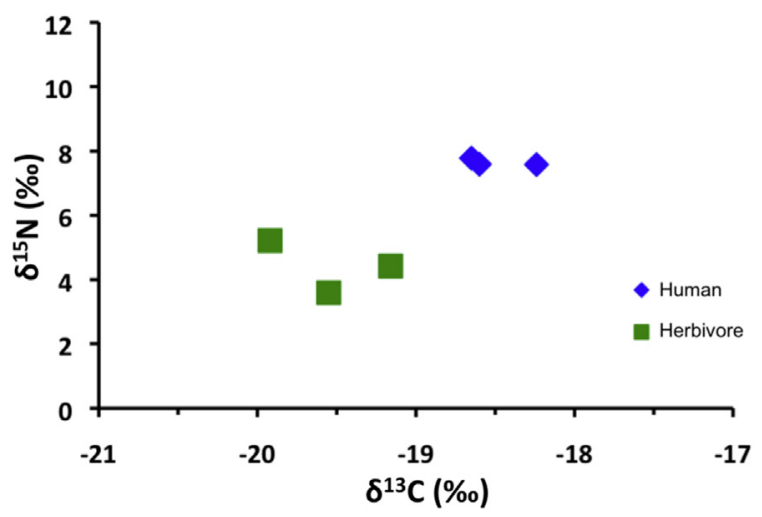

Fig. 4. Plot of human and animal bone collagen $\delta^{13} \mathrm{C}$ and $\delta^{15} \mathrm{~N}$ values from Penya del Comptador.

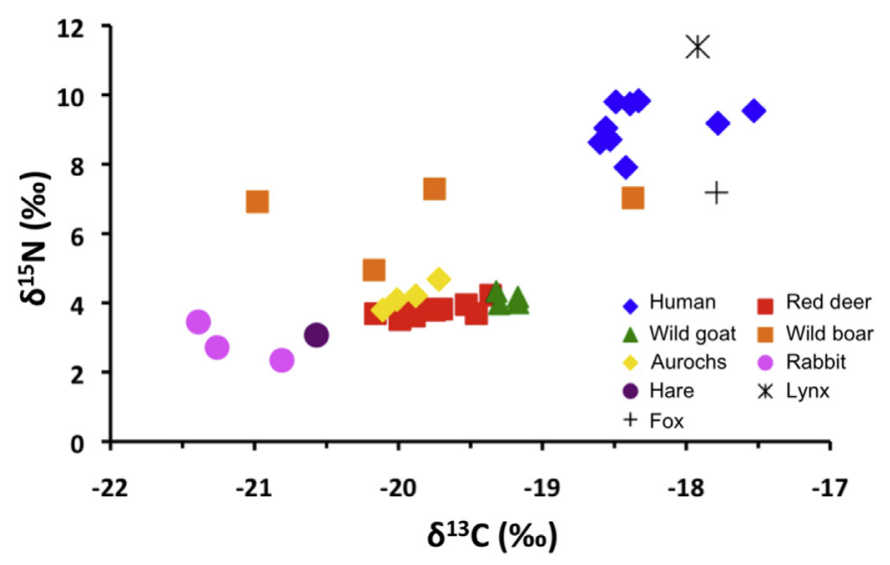

Fig. 5. Plot of human an animal bone collagen $\delta^{13} \mathrm{C}$ and $\delta^{15} \mathrm{~N}$ values from Cingle del Mas Nou.

\subsection{Santa Maira and Penya del Comptador isotope data}

Bone samples from 3 humans and 27 animals were taken from the Mesolithic layers of Santa Maira, and from Penya del Comptador bones of 3 humans and 3 unidentified medium-sized herbivores. All human remains and almost all terrestrial animal samples yielded enough collagen at the $>30 \mathrm{kDa}$ fraction for analysis in duplicate, and met published quality controls (Ambrose, 1993; Van Klinken, 1999). Only 2 of the 8 fish bones sampled had good quality collagen in the $>30 \mathrm{kDa}$ fraction enough for one measurement (the other samples yielded no collagen). Collagen extracted from one human bone from each site (S-EVA 9051 and 9097) was sent to the Radiocarbon Accelerator Unit of Oxford University for analysis. The resulting dates (Table 1, Fig. 6) are compatible with the archaeological findings at the sites and the Mesolithic period at the region.

The herbivore $\delta^{13} \mathrm{C}$ values from Santa Maira $(m=-20.3 \pm 1.2$ [1 $\sigma] \%$, min: $-21.7 \%$ max: $-18.4 \%$ ) and Penya del Comptador $(m=-19.5 \pm 0.4[1 \sigma] \%$, min: $-19.9 \%$, max: $-19.2 \%$ o $)$ are typical values for a terrestrial $C_{3}$ European ecosystem (De Niro and Epstein, 1978; Schwarcz and Schoeninger, 1991). Most herbivores group between -20 and $-18.5 \%$, and the presence of rabbits depleted in ${ }^{13} \mathrm{C}$ increases the standard deviation. The carnivore $\delta^{13} \mathrm{C}$ values $(m=-19.1 \pm 0.4(1 \sigma) \%$, min: $-19.4 \%$, max: $-18.4 \%$ ) are consistent with the majority of herbivore values and a terrestrial $C_{3}$ food web. The herbivore $\delta^{15} \mathrm{~N}$ values from Santa Maira $(m=3.7 \pm 0.8[1 \sigma] \%$, min: $2.6 \%$, max: $4.8 \%$ ) and Penya del Comptador $(m=4.4 \pm 0.8(1 \sigma) \%$, min: $3.6 \%$, max: $5.2 \%$ ) define the trophic baseline of the local mammalian food web. The carnivore $\delta^{15} \mathrm{~N}$ mean value is $6.0 \pm 0.9(1 \sigma) \%$, which is almost $2.5 \%$ o more positive than the Santa Maira herbivore mean value $(3.7 \%$ ), consistent with these species being a trophic level above the herbivores at the site (De Niro and Epstein, 1981; Minagawa and Wada, 1984). The fish $(n=2) \delta^{13} \mathrm{C}$ mean value is $-15.2 \%$ and its $\delta^{15} \mathrm{~N}$ mean value is $8.5 \%$, which is low for purely marine fish (Chisholm et al., 1982; Schoeninger and De Niro, 1984) but could be result of the lifecycle of the species sampled, Sparidae and Mugillidae, which live for part of their life in rivers or estuaries.

All humans from Santa Maira have $\delta^{13} \mathrm{C}$ and $\delta^{15} \mathrm{~N}$ mean values of $-18.0 \pm 0.2(1 \sigma) \%$ (min: $-18.1 \%$ max: $-17.8 \%$ o ) and $9.3 \pm 0.6(1 \sigma)$ $\%$ (min: $9.0 \%$, max: $10.3 \%$ ) respectively. Their carbon values describe a diet where the protein was based mainly on terrestrial $C_{3}$ resources. Their nitrogen values clearly situate them in a higher trophic level than both the herbivores (almost 6\% higher) and the carnivores ( $3 \%$ higher). Both $\delta^{13} \mathrm{C}$ and $\delta^{15} \mathrm{~N}$ values together suggest that the diet included enough marine protein as to positively shift the carbon values almost 3\% from the herbivore mean value and the nitrogen values 3\% higher than the carnivores. There is no trace of freshwater protein consumption in the diet.

The $\delta^{13} \mathrm{C}$ mean value for the humans of Penya del Comptador is $-18.5 \pm 0.2(1 \sigma) \%$ ( $\mathrm{min}:-18.7 \%$ max: $-18.2 \%$ ), which is consistent with a diet based mainly on $\mathrm{C}_{3}$ terrestrial resources. Their $\delta^{15} \mathrm{~N}$ mean value is of $7.7 \pm 0.1(1 \sigma) \%$ ( $\min : 7.6 \%$, max: $7.8 \%$ o), which situates humans in a clear higher trophic position than the fauna (probably herbivores, $3 \%$ higher). The combined $\delta^{13} \mathrm{C}$ and $\delta^{15} \mathrm{~N}$ mean values also indicate that probably all the protein in the diet was from terrestrial $C_{3}$ animal sources.

The Santa Maira humans group tightly together, as observed in Fig. 3, showing no difference in protein input regardless of their expected sex or age. The terrestrial animals most likely consumed by the humans were the ibex, wild boar and red deer. There is no clear isotopic evidence of significant rabbit consumption by this population as suggested by zooarchaeological analyses on the Mesolithic levels of the site (Aura et al., 2006, 2009). Contrary to what is observed for Santa Maira, the humans from Penya del Comptador show no evidence for marine protein consumption and consume a largely homogeneous terrestrial $C_{3}$ diet (Fig. 4).

\subsection{Cingle del Mas Nou isotope data}

Samples from 9 humans ( 3 adults, 1 sub-adult, 3 infants, 2 perinatals) and 36 animals, of 7 different species, were taken from the Mesolithic contexts. All human and almost all terrestrial animal bones yielded enough collagen to run samples in duplicate. Collagen passed quality control criteria (Ambrose, 1993; Van Klinken, 1999), indicating good preservation in the $>30 \mathrm{kDa}$ fraction. Samples S-EVA 17066 and 17096 yielded enough good collagen for only one run. Collagen extracted from the bones of two humans from Cingle del Mas Nou (S-EVA 9084 and S-EVA 9089) was also sent to the Radiocarbon Accelerator Unit of Oxford University for analysis. These two dates (Table 1, Fig. 6) are compatible with the archaeological findings and the Mesolithic period at the region.

The Cingle del Mas Nou herbivore $\delta^{13} \mathrm{C}$ values $(m=-19.9 \pm 0.6$ $(1 \sigma) \%$, min: $-21.4 \%$, max: $-18.8 \%$ ) are typical of a terrestrial $C_{3}$ European ecosystem (De Niro and Epstein, 1978; Schwarcz and Schoeninger, 1991). The tightly grouped herbivore $\delta^{15} \mathrm{~N}$ values ( $m=3.8 \pm 0.5(1 \sigma) \%$, min: $2.3 \%$, max: $4.7 \%$ ) set the 'baseline' for the local food chain and interpretation of human dietary values. Omnivores (Sus scrofa) present carbon and nitrogen values more positive than the herbivore ones: $\delta^{13} \mathrm{C}$ mean value of $-19.8 \pm 1.1$ $(1 \sigma) \%$, and $\delta^{15} \mathrm{~N}$ mean value of $6.6 \pm 1.1(1 \sigma) \%$. The carnivores have more positive $\delta^{13} \mathrm{C}$ values than the herbivores: -17.9 and 


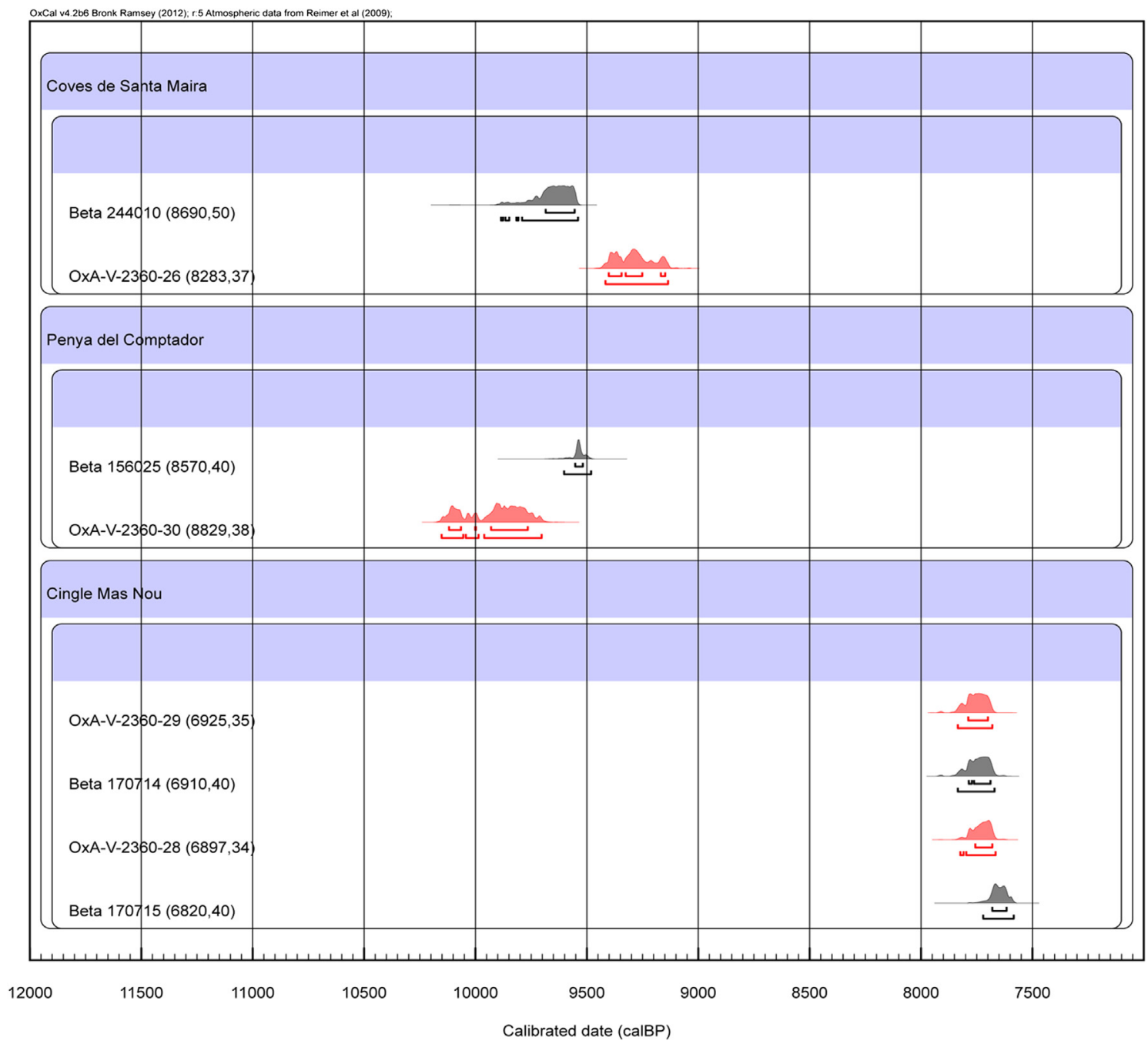

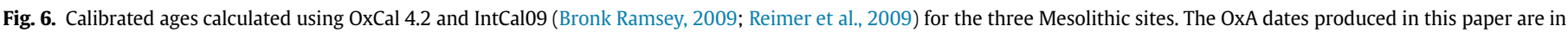
red. Beta results are in black. (For interpretation of the references to colour in this figure legend, the reader is referred to the web version of this article.)

$-17.8 \%$. Their $\delta^{15} \mathrm{~N}$ values are $7.2 \%$ and $11.4 \%$, which situate them on a higher trophic food web position than the herbivores (De Niro and Epstein, 1981; Minagawa and Wada, 1984). This unusual range of isotopic values could be explained by the variety of foods (eggs, invertebrates, amphibians, reptiles, fish, small mammals) consumed by modern foxes and lynxes within any particular ecosystem (Fedriani, 1996, 1997; Fernández and Ruiz, 2005; Guitian and Bermejo, 1989).

The human $\delta^{13} \mathrm{C}(m=-18.3 \pm 0.4(1 \sigma) \%$, min: $-18.6 \%$, max: $-17.5 \%$ ) and $\delta^{15} \mathrm{~N}(m=9.2 \pm 0.7(1 \sigma) \%$, min: $7.9 \%$, max: $9.8 \%$ o values indicate that the diet was mainly based on $\mathrm{C}_{3}$ terrestrial resources, but also suggest that a small amount of marine food was possibly consumed by all the population (Chisholm et al., 1982; Schoeninger and De Niro, 1984), including two individuals (S-EVA 9089 and 9090) that might have consumed it on a more regular basis than the others. They also situate the humans in a higher trophic level than the herbivores (5.5\% higher) and within the range of carnivore values. The isotope values for individuals do not appear to differ according to sex or age (see Table 4), not even considering the infant or perinatal individual differences that could be attributed to social practices such as breastfeeding (Fogel et al., 1989; Fuller et al., 2006) or weaning (Herring et al., 1998).

Most humans ( 2 adult males, 1 adult female, 1 adolescent, 3 infants) group tightly around $\delta^{13} \mathrm{C}$ values of $-18.5 \%$ and $\delta^{15} \mathrm{~N}$ values of $8-10 \%$, as observed in Fig. 5. This main group shows some indication of marine protein input in the diet, but the majority of the protein in their diets was most likely red deer, ibex and aurochs. Two infants have more positive $\delta^{13} \mathrm{C}$ values $(-17.5 \%$ o but similar $\delta^{15} \mathrm{~N}$ ones to that of the main group. This is probably not due to breastfeeding as there is no increase in nitrogen isotope values, which we would expect with breastfeeding (Fuller et al., 2006). This isotopic pattern could be explained by a $\mathrm{C}_{4}$ or marine resource consumption in the diet. The first option seems unlikely, because at this time period there are no known edible $C_{4}$ plants in the Iberian Peninsula. The second possibility therefore seems the best explanation for the high carbon values. This site is today almost $50 \mathrm{~km}$ away from the coast, so either the marine food was moved to the site or these humans spent time on the coast sometime during the year. Unfortunately no aquatic remains have been found at the site, and thus no marine or freshwater isotopic reference exists to compare the human values to.

\section{Discussion}

The results from the three Eastern Iberian Mesolithic sites studied show that the diet of these populations was mainly a terrestrial $C_{3}$ diet. There is no clear isotopic evidence for freshwater food intake on the diet at any of the sites, although it must be 
considered that freshwater values are highly variable and that remains were unfortunately not available for analysis. There is no isotopic evidence of marine protein intake at Penya del Comptador, but evidence for some marine protein consumption at the sites of Santa Maira and Cingle del Mas Nou. At all three sites the majority of protein was from $C_{3}$ animal sources.

This dietary pattern is similar to the stable isotope results from other Mediterranean Mesolithic sites studied, but differs from other European Mesolithic populations. Few datasets for Mesolithic Western and Central Mediterranean populations have been published so far, so this described pattern could change with new isotopic studies. In Atlantic (i.e. Richards and Hedges, 1999; Richards et al., 2003; Schulting et al., 2008; Schulting and Richards, 2002) and Baltic (i.e. Eriksson, 2003; Lidén et al., 2004) Mesolithic sites there exists a considerable consumption of aquatic resources, while in the Mediterranean populations it is almost absent. In Mesolithic sites from Italy (Francalacci, 1988; Mannino et al., 2011), Croatia (Lightfoot et al., 2011) and Corsica (Vigne, 2004) there is no isotopic evidence of significant levels of marine food consumption.

Isotope results from two Mesolithic Eastern Iberian sites have also been published: the shell midden of El Collado (García-Guixé et al., 2006) and the Late Mesolithic site of La Corona (SalazarGarcía et al., 2013). All $\delta^{13} \mathrm{C}$ and $\delta^{15} \mathrm{~N}$ values from these Mediterranean Iberian sites are plotted in Fig. 7, together with the sites from this study. Humans from Penya del Comptador, La Corona and some from Cingle de Mas Nou and El Collado clearly present a completely terrestrial diet that shows no isotopic evidence for aquatic resource consumption (the individual from La Corona with a highest carbon and nitrogen value is an infant whose values are positively shifted due to the breastfeeding influence). The humans from Santa Maira and some from Cingle del Mas Nou and El Collado show a significant marine protein input in the diet, up to about 25\% for the two individuals with the highest $\delta^{13} \mathrm{C}$ values (García-Guixé et al., 2006).

All of this shows both an inter- and an intra-heterogeneity of the diet of the last hunter-gatherer societies of Eastern Iberia. The geographic location is sometimes the best predictor of the diet of these populations (Fig. 1). It is expected that populations that lie far away from the coast, such as La Corona or Penya del Comptador, show no isotopic evidence for marine food in the diet, or that populations like El Collado, which lie on the coast, consumed some marine protein. There are some sites like Santa Maira or Cingle del Mas Nou that lie in the mid-mountain area, far from the coast,

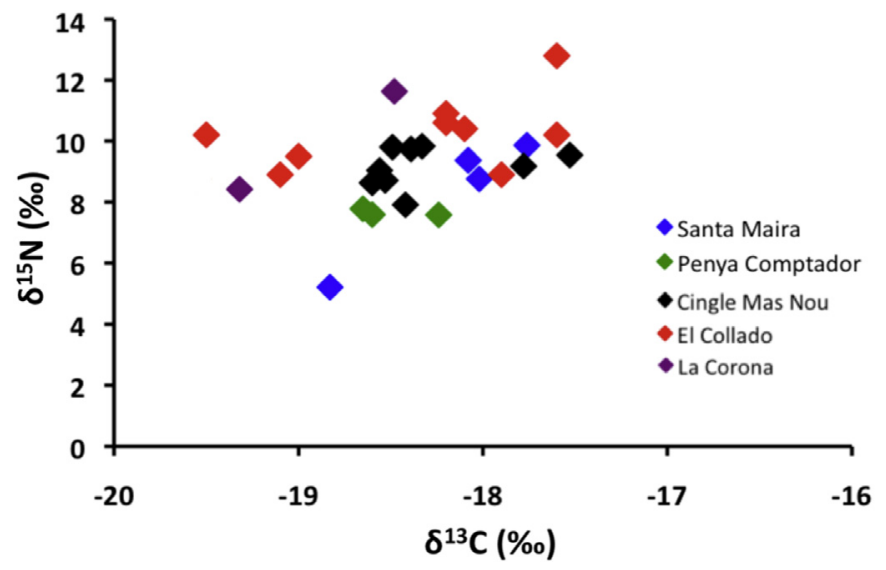

Fig. 7. Plot of human bone collagen $\delta^{13} \mathrm{C}$ and $\delta^{15} \mathrm{~N}$ values from the Eastern Iberia Mesolithic sites including those presented here and results from the sites of El Collado (García-Guixé et al., 2006) and La Corona (Salazar-Garcíá et al., 2013).

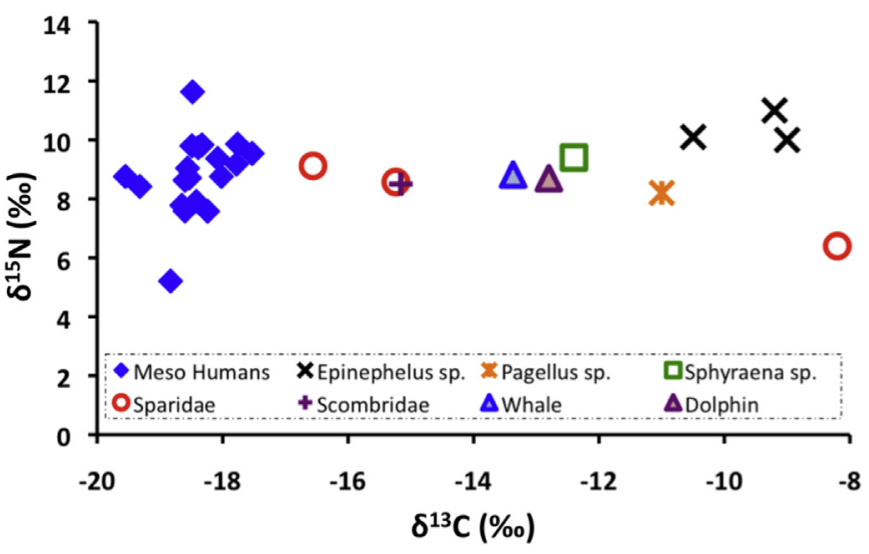

Fig. 8. Plot of bone collagen values $\delta^{13} \mathrm{C}$ and $\delta^{15} \mathrm{~N}$ values of Eastern Iberian Mesolithic humans studied and with values of archaeological marine animals from Santa Maira, Cova de l'Or (Salazar-García, 2012a), La Vital (Salazar-García, 2012b), Cova des Riuets (García-Guixé et al., 2010) and Monte Leone (Vigne, 2004).

where the population had enough of a marine signal in their collagen to likely imply an inland-coastal population mobility or an existence of a wide exchange network that connects these sites with other populations living on the coast. This was suggested in a published model of settlement population dynamics for the region that proposes the existence of fifteen Mesolithic groups occupying $700-1200 \mathrm{~km}^{2}$ of land with a diameter of $25-35 \mathrm{~km}$ from the littoral up to the upper-mountain area (Aura, 2001; Martí et al., 2009). Furthermore, the development of the first necropolis in this region at 9500 calBP is consistent with the presence of contemporary shelters, caves and open-air sites in the same region, suggesting the integration of different human groups in a same territory and probably also indicating an increase in sedentism (Aura, 2009).

For Penya del Comptador and La Corona the preliminary zooarchaeological finds are compatible with the isotope evidence of a mainly terrestrial diet. At Penya del Comptador the faunal remains are few and poorly preserved, exhibiting a lack of fish and shellfish, although that may be due to post-depositional processes not preserving the fish and shellfish remains (Aura et al., 2006). For La Corona only terrestrial animals have been found in the Mesolithic levels, except for some marine shellfish (Columbella rustica) used as parts of body ornaments and never attributed to being the products of food consumption (Salazar-García et al., 2013). The same cannot be said for Cingle del Mas Nou, where the faunal study shows that red deer and goat were the most abundant species and there are no freshwater or marine remains (Olària et al., 2005), while the isotopic study suggests marine consumption in the diets of some of the humans from the site.

The faunal analysis from the upland site of Santa Maira is much more complete and identifies a diet based on terrestrial animals with the ibex as the main dietary element. It shows an increase in the relative presence of the minority taxa from the Late Upper Palaeolithic to the Mesolithic levels, namely forest species and small carnivores. Rabbit remains are still the most abundant and show cutmarks from whole animal processing (Aura et al., 2009). The stable isotope analysis shows that rabbit was not a main protein source in human diets at this site, perhaps because of the relatively low amount of meat on rabbits compared to larger herbivores. Although not present in great quantities, edible shellfish (Mytilus edulis, Cardium sp.) and fish remains (Anguilla anguilla, Sparus aurata, Diplodus vulgaris, Sparus sp., Mugill sp.) increase considerably in frequency in the Mesolithic levels of Santa Maira compared to previous periods (Aura et al., 2008, 2009), probably 
related to the raised sea level and the possible subsequent increase in movement between these inland valley sites and the coastal plain, which matches the isotopic evidence for human marine consumption at the site.

What we call here the "fish paradox" should be assessed when addressing fish consumption by stable isotopes at Western Mediterranean sites such as Santa Maira and Cingle del Mas Nou. Typically, a marine human value of around -10 to $-12 \%$ o $\delta^{13} \mathrm{C}$ is considered to represent a 100\% marine diet (Chisholm et al., 1982; Schoeninger and De Niro, 1984). However, the published prehistoric fish remains from the Western Mediterranean are more negative than expected, with highly ranging $\delta^{13} \mathrm{C}$ values from -8 to $-16 \%$. In Fig. 8 all archaeological Mesolithic humans are plotted with the prehistoric fish published from the Western Mediterranean: Santa Maira (Mesolithic), Cova de l'Or (Early Neolithic, Salazar-García, 2012a), La Vital (Late Neolithic, Salazar-García, 2012b), Cova des Riuets (Bronze Age, GarcíaGuixé et al., 2010) and Monte Leone (Mesolithic, published in Vigne, 2004). Sometimes the more negative than expected fish $\delta^{13} \mathrm{C}$ values may be caused simply because some fish (i.e. Sparidae and Mugillidae) are estuarine-marine, or because some whales are filter feeders that eat a large quantity of small low-trophic level organisms. The issue is that by consuming some marine foods with more negative isotopic values, it is possible that in some of these sites a "marine diet" could actually result in a more negative human $\delta^{13} \mathrm{C}$ carbon isotope value than that usually expected. If so, if we consider that the fish remains from Santa Maira are mainly from Sparidae and Mugillidae, it is possible that their contribution to human diets could have been significant, highlighting the importance of measuring fish remains from archaeological sites alongside the humans whenever possible in order to more accurately quantify the amount of aquatic protein consumed in the diet.

Although probably less evident than marine consumption through isotopic evidence, the archaeological Mesolithic Western Mediterranean sequence also shows the use of vegetable resources (Buxó, 1997; Holden et al., 1995; Zapata et al., 2002). Plenty of seed and fruit remains have been recovered at Eastern Iberian Mesolithic sites like Santa Maira, mainly from shrubs and trees (Crataegus sp., Juniperus sp., Olea europaea var. sylvestris, Pistacia sp., Quercus sp., Sorbus sp., Vitis vinifera var. sylvestris) and also from legumes (Lathyrus/Vicia) (Antolín et al., 2010; Aura et al., 2005). The significant consumption of these plants is not indicated by the isotope analysis, likely due to the relatively low amounts of protein in plants compared to herbivore meat. However, it could also indicate that plants were not regularly consumed, and could also be used for other purposes (preparing glues, as part of firewood, etc.).

\section{Conclusions}

There is no clear direct relationship between proximity to the coast and consumption of marine resources in the Eastern Iberian Mesolithic up to a certain distance from the coast. The type of site (open-air, rock shelter-cave) is also not related to the level of seafood consumption. Therefore, the use of marine resources by the Mesolithic people in Eastern Iberia could probably be explained by demographic and social factors.

The observed pattern of different use of resources showing variability between sites suggests a constant high inland-coastal mobility amongst these populations. The northern inland site of Cingle del Mas Nou suggests a human consumption of some marine resources and thus a connection with the coast. From the southern sample, the results from the coastal site of El Collado and the inland site of Santa Maira (30 km from sea) suggest an unequal and low consumption of marine resources amongst individuals, while the data from Penya del Comptador and La Corona ( $>40 \mathrm{~km}$ from the coast) show no isotopic nor archaeozoological evidence for marine resource consumption. Future isotope studies focussing on mobility, such as strontium and sulphur, will help in interpreting the relationship between marine consumption and coastal-inland human mobility in this region.

\section{Acknowledgements}

Part of this research was funded by the Department of Human Evolution (Prof. Jean-Jacques Hublin) of the Max-Planck Institute for Evolutionary Anthropology, and part was funded by the Spanish Ministerio de Ciencia y Tecnología through an FPU predoctoral scholarship (ref. AP2005-1509). DCSG would like to thank María Borao and Tono Vizcaíno for their help in sampling Cingle del Mas Nou. All authors thank the reviewers for their useful comments.

\section{References}

Alday, A., 2006. El Mesolítico de muescas y denticulados en la cuenca del Ebro y el litoral mediterráneo peninsular. Diputación Foral de Álava. Departamento de Cultura, Álava.

Ambrose, S.H., 1993. Isotopic analysis of paleodiets: methodological and interpretative considerations. In: Stanford, M.K. (Ed.), Investigations of Ancient Human Tissue: Chemical Analyses in Anthropology. Gordon and Breach Science Publishers, Langhorne, pp. 59-130.

Ambrose, S.H., Norr, L., 1993. Experimental evidence for the relationship of the carbon isotope ratios of whole diet and dietary protein to those of bone collagen and carbonate. In: Lambert, J.B., Gruppe, G. (Eds.), Prehistoric Human Bone: Archaeology at the Molecular Level. Springer Verlag, Berlin, pp. 1-37.

Antolín, F., Caruso, L., Mensua, C., Olària, C., Piquè, R., Alonso, N., 2010. Forest resources exploitation in the Late Mesolithic and Early Neolithic site of Cova Fosca (Ares del Maestre, Castelló, Spain). In: Delhon, C., Théry-Parisot, I., Thiébault, S. (Eds.), Des Hommes et des Plantes. Exploitation du milieu et gestion des resources végétales de la Préhistoire à nos jours, XXXe Rencontres Internationales d'Archéologie et d'Historie d'Antibes. Éditions APDCA, Antibes, pp. 317-327.

Aura, J.E., 2001. Cazadores emboscados. El Epipaleolítico en el País Valenciano. In: Villaverde, V. (Ed.), De Neandertales a Cromañones. El inicio del poblamiento humano en tierras valencianas. Publicacions de la Universitat de València, València, pp. 219-238.

Aura, J.E., 2009. Uno de los Nuestros. Notas para una Arqueología de las prácticas funerarias de los cazadores prehistóricos de la Península Ibérica. In: Pérez Fernández, A., Soler Mayor, B. (Eds.), Restos de Vida-Restos de Muerte. Museu de Prehistòria de València, València, pp. 31-44.

Aura, J.E., Carrión-Marco, Y., Estrelles, E., Pérez-Jordà, G., 2005. Plant economy of hunter-gatherer groups at the end of the last Ice Age: plant macroremains from the cave of Santa Maira (Alacant, Spain) ca. 12,000-9000 B.P. Veg. Hist. Archaeobot. 14, 542-550.

Aura, J.E., Carrión-Marco, Y., García-Puchol, O., Jardón, P., Jordá, J.F., Molina, L., Morales-Pérez, J.V., Pascual-Benito, J.L., Pérez-Jordà, G., Pérez, M., Rodrigo, M.J., Verdasco, C., 2006. Epipaleolítico-Mesolítico en las comarcas centrales valencianas. In: Alday, A. (Ed.), El mesolítico de muescas y denticulados en la Cuenca del Ebro y el litoral mediterráneo peninsular. Diputación Foral de Álava, Vitoria-Gasteiz, pp. 65-120.

Aura, J.E., Miret, C., Morales-Pérez, J.V., 2008. Coves de Santa Maira (Castell de Castells, La Marina Alta, Alacant): Campaña de 2008. Saguntum 40, 227-232.

Aura, J.E., Jordá, J.F., Morales-Pérez, J.V., Pérez-Ripoll, M., Villalba, M.P., Alcover, J.A. 2009. Economic transitions in finis terra: the western Mediterranean of Iberia, 15-7 ka BP. Before Farm., 2009/2, article 4.

Aura, J.E., Jordá, J.F. Montes, L. Utrilla, P., 2011. Human responses to Younger Dryas in the Ebro valley and Mediterranean watershed (Eastern Spain). Quat. Int. 242, $348-359$.

Badal, E., Carrión, Y., 2001. Del Glacial a l'Interglacial: Els paisatges vegetals a partir de les restes carbonitzades trobades en les coves d'Alacant. In: Villaverde, V. (Ed.), De Neandertales a Cromañones. El inicio del poblamiento humano en tierras valencianas. Publicacions de la Universitat de València, València, pp. 21-40.

Bronk Ramsey, C., 2009. Bayesian analysis of radiocarbon dates. Radiocarbon 51, $337-360$.

Brown, T.A., Nelson, D.E., Vogel, J.S., Southon, J.R., 1988. Improved collagen extraction by modified Longin method. Radiocarbon 30, 171-177.

Buxó, R., 1997. La Arqueología de las Plantas. Editorial Crítica, Barcelona.

Chisholm, B.S., Nelson, D.E., Schwarcz, H.P., 1982. Stable carbon isotope ratios as a measure of marine versus terrestrial protein in ancient diets. Science 216, 1131-1132.

De Miguel, M.P., 2009. Informe antropológico de Santa Maira (Unpublished).

De Niro, M.J., 1985. Postmortem preservation and alteration of in vivo bone collagen isotope ratios in relation to palaeodietary reconstruction. Nature 317, 806-809.

De Niro, M.J., Epstein, S., 1978. Influence of diet on the distribution of carbon isotopes in animals. Geochim. Cosmochim. Acta 42, 495-506.

De Niro, M.J., Epstein, S., 1981. Influence of diet on the distribution of nitrogen isotopes in animals. Geochim. Cosmochim. Acta 49, 97-115. 
Eriksson, G., 2003. Norm and Difference. Stone Age Dietary Practice in the Baltic Region. In: Theses and Papers in Scientific Archaeology, vol. 5. Archaeological Research Laboratory, Stockholm.

Fedriani, J.M., 1996. Dieta anual del zorro Vulpes vulpes en dos hábitats del Parque Nacional de Doñana. Doñana Acta Vertebr. 23, 143-152.

Fedriani, J.M., 1997. Relaciones interespecíficas entre el lince ibérico, Lynx pardina, el zorro, Vulpes vulpes, y el tejón, Meles meles, en el Parque Nacional de Doñana. Universidad de Sevilla, Sevilla.

Fernández, J.M., Ruiz de Azua, N., 2005. Dieta y solapamiento trófico primaveral del zorro rojo Vulpes vulpes y de Martes sp. en simpatría en Álava (Norte de España). Ecología 19, 167-182.

Fogel, M., Tuross, N., Owsley, D.W., 1989. Nitrogen Isotope Tracers of Human Lactation in Modern and Archaeological Populations. In: Carneige Institute Year Book, vol. 88, pp. 111-117.

Fortea, J., 1973. Los Complejos Microlaminares y Geométricos del Epipaleolítico Mediterráneo Español. In: Memorias del Seminario de Prehistoria y Arqueología, vol. 4. Universidad de Salamanca, Salamanca.

Francalacci, P., 1988. Comparison of archaeological, trace element and stable isotope data from two Italian coastal sites. Riv. Antropol. 66, 239-250.

Fuller, B.T., Fuller, J.L., Harris, D.A., Hedges, R.E.M., 2006. Detection of breastfeeding and weaning in modern human infants with carbon and nitrogen stable isotope ratios. Am. J. Phys. Anthropol. 129, 279-293.

García-Guixé, E., Subira, M.E., Richards, M.P., 2006. Paleodiets of humans and fauna from the Spanish Mesolithic site of El Collado. Curr. Anthropol. 47, 549-556.

García-Guixé, E., Subirà, M.E., Marlasca, R., Richards, M.P., 2010. $\delta^{13} \mathrm{C}$ and $\delta^{15} \mathrm{~N}$ in ancient and recent fish bones from the Mediterranean Sea. J. Nordic Archaeol. Sci. $17,83-92$.

García-Puchol, O., Aura, E., McClure, S.B., 2012. Mesolithic and Neolithic funerary practices in the Central Mediterranean region of Spain. In: Gibaja, J.F., Carvalho, A.F., Chambon, P. (Eds.), Funerary Practices in the Iberian Peninsula from the Mesolithic to the Chalcolithic. Archaeopress (BAR S2417), Oxford, pp. 41-50.

Guitian, J., Bermejo, T., 1989. Nota dietas de carnívoros en índice de abundancia en una reserva de caza del norte de España. Doñana Acta Vertebr. 16, 319-323.

Hedges, R.E.M., Reynard, L.M., 2007. Nitrogen isotopes and the trophic level of humans in archaeology. J. Archaeol. Sci. 34, 1240-1251.

Hedges, R.E.M., Clement, J.G., Thomas, C.D.L., O'Connell, T.C., 2007. Collagen turnover in the adult femoral mid-shaft: modeled from anthropogenic radiocarbon tracer measurements. Am. J. Phys. Anthropol. 133, 808-816.

Hernández, M., Ferrer, P., Català, F., 1988. Arte Rupestre en Alicante. Fundación Banco Exterior, Alacant.

Herring, D.A., Saunders, S.R., Katzenberg, M.A., 1998. Investigating the weaning process in past populations. Am. J. Phys. Anthropol. 105, 425-439.

Holden, T.G., Hather, J.G., Watson, J.P.N., 1995. Mesolithic plant exploitation at the Roc del Migdia, Catalonia. J. Archaeol. Sci. 22, 769-778.

Howland, M.R., Corr, L.T., Young, S.M.M., Jones, V., Jim, S., Van der Merwe, N.J., Mitchell, A.D., Evershed, R.P., 2003. Expression of the dietary isotope signal in the compound-specific delta-13 values of pig bone lipids and amino acids. Int. J. Osteoarchaeol. 13, 54-65.

Jim, S., Jones, V., Ambrose, S.H., Evershed, R.P., 2006. Quantifying dietary macronutrient sources of carbon for bone collagen biosynthesis using natural abundance stable carbon isotope analysis. Br. J. Nutr. 95, 1055-1062.

Jordá Pardo, J.F., Maestro González, A., Aura Tortosa, J.E., Álvarez Fernández, E., Avezuela Aristu, B., Badal García, E., Morales Pérez, J.V., Pérez Ripoll, M., Villalba Currás, M.P., 2011. Evolución paleogeográfica, paleoclimática y paleoambiental de la costa meridional de la Península Ibérica durante el Pleistoceno superior. El caso de la Cueva de Nerja (Málaga, Andalucía, España). Bol. Real Soc. Españ. Hist. Nat. Sección Geol. 105, 137-147.

Katzenberg, M.A., 2000. Stable istope analysis: a tool for studying past diet, demography and life history. In: Katzenberg, M.A., Saunders, S.R. (Eds.), Biological Anthropology of the Human Skeleton. Willey-Liss, New York, pp. 305-328.

Lee-Thorp, J.A., 2008. On isotopes and old bones. Archaeometry 50, 925-950.

Lidén, K., Eriksson, G., Nordqvist, B., Gotherstriom, A., Bendixen, E., 2004. The wet and the wild followed by the dry and the tame - or did they occur at the same time? Diet in Mesolithic-Neolithic southern Sweden. Antiquity 78, 23-33.

Lightfoot, E., Boneva, B., Miracle, P.T., Slaus, M., O'Connell, T.C., 2011. Exploring the Mesolithic and Neolithic transition in Croatia through isotopic investigations. Antiquity 85, 73-86.

Mannino, M.A., Thomas, K.D., Leng, M.J., Di Salvo, R., Richards, M.P., 2011. Stuck to the shore? Investigating prehistoric hunter-gatherer subsistence, mobility and territoriality in a Mediterranean coastal landscape through isotope analyses on marine mollusc shell carbonates and human bone collagen. Quat. Int. 244, 88-104.

Martí, B., Aura, J.E., Juan, J., García-Puchol, O., Fernández, J., 2009. El mesolítico geométrico de tipo “Cocina” en el País Valenciano. In: Utrilla, M.P., Montes, L. (Eds.), El Mesolítico Geométrico en la Península Ibérica, Monografías Arqueológicas, vol. 44. Universidad de Zaragoza, Zaragoza, pp. 205-258.

Minagawa, M., Wada, E., 1984. Stepwise enrichment of ${ }^{15} \mathrm{~N}$ along food chains: further evidence and the relation between ${ }^{15} \mathrm{~N}$ and animal age. Geochim. Cosmochim. Acta 48, 1135-1140.

Miret, C., 2007. Estudi de la tecnologia lítica de la Unitat 3 de les Coves de Santa Maira -boca Oest- (Castell de Castells, Marina Alta, Països Catalans). Saguntum 39, 85-102.

Olària, C., 2002-2003. La muerte como rito trascendental. Los rituales funerarios del epipaleolítico-mesolítico y su probable influencia en el mundo megalítico. Quad. Prehist. Arqueol. Castellon 23, 85-106.
Olària, C., 2007. Un passeig per a Prehistòria: Guia de l'art rupestre Llevantí de Castelló. Universitat Jaume I de Castelló, Castelló.

Olària, C., Gusi, F., Gómez, J.L., 2005. Un enterramiento Meso-Neolítico en el Cingle del Mas Nou (Ares del Maestre, Castellón) del 7000 BP en territorio de arte levantino. In: Arias, P., Ontañón, R., García-Moncó, C. (Eds.), Actas del III Congreso del Neolítico en la Península Ibérica (Santander, 5-8 octubre 2003), Monografías del Instituto Internacional de Investigaciones Prehistóricas de Cantabria, vol. 1. Universidad de Cantabria, Santander, pp. 615-623.

Olària, C., Gusi, F., López, J.L., 2010. Epipaleolithic and Mesolithic Burial’s from 12,000 to $7000 \mathrm{BP}$ in Levantin territory art rock. In: Oosterbeek, L. (Ed.), Proceedings of the XV World Congress of the International Union for Prehistoric and Protohistoric Sciences. Archaeopress (BAR S2108), Oxford, pp. 115-123.

Reimer, P.J., Baillie, M.G.L., Bard, E., Bayliss, A., Beck, J.W., Blackwell, P.E., BronkRamsey, C., Buck, C.E., Burr, G., Edwards, R.L., Friedrich, M., Grootes, P.M. Guilderson, T.P., Hajdas, I., Heaton, T.J., Hogg, A.G., Hughen, K.A., Kaiser, K., Kromer, B., McCormac, F.G., Manning, S., Reimer, R.W., Richards, D.A., Southon, J.R., Talamo, S., Turner, C.S.M., van der Plicht, J., Weyhenmeyer, C.E., 2009. IntCal09 and Marine09 radiocarbon age calibration curves, 0-50.000 years cal BP. Radiocarbon 51 (4), 1111-1150.

Pérez Ripoll, M., 1992. Marcas de carníceria, fracturas intencionadas y mordeduras de carnívoros en huesos prehistóricos del mediterráneo español. Instituto Juan Gil-Albert, Alacant.

Richards, M.P., Hedges, R.E.M., 1999. Stable isotope evidence for similarities in the types of marine foods used by Late Mesolithic humans at sites along the Atlantic coast of Europe. J. Archaeol. Sci. 26, 717-722.

Richards, M.P., Schulting, R.J., Hedges, R.E.M., 2003. Sharp shift in diet at onset of Neolithic. Nature 425, 366.

Sage, R.F., Wedin, D.A., Li, M., 1999. The Biogeography of $C_{4}$ photosynthesis: patterns and controlling factors. In: Sage, R.F., Monson, R.K. (Eds.), $C_{4}$ Plant Biology Academic Press, London, pp. 313-373.

Salazar-García, D.C., 2012a. Isótopos, dieta y movilidad en el País Valenciano. Aplicación a restos humanos del Paleolítico Medio al Neolítico Final. Doctoral thesis. Universitat de València, València.

Salazar-García, D.C., 2012b. Aproximación a la dieta de la población calcolítica de La Vital a través del análisis de isótopos estables del carbono y del nitrógeno sobre restos óseos. In: Perez Jordá, G., Bernabeu Aubán, J., Carrión Marco, Y., GarcíaPuchol, O., Molina Balaguer, L.L., Gómez Puche, M. (Eds.), La Vital (Gandia, Valencia). Vida y muerte en la desembocadura del Serpis durante el III y el milenio a.C. Museu de Prehistòria de València-Diputación de Valencia (T.V. 113), València, pp. 139-143.

Salazar-García, D.C., Fernández-López de Pablo, J., Subirà, M.E., Roca-Togores, C. Gómez-Puche, M., Richards, M.P., Esquembre-Bebiá, M.A., 2013. Late Mesolithic burials of Casa Corona (Villena, Spain): direct radiocarbon and paleodietary evidence of last forager populations in Eastern Iberia. J. Archaeol. Sci. 40, 671-680.

Schoeller, D.A., 1999. Isotope fractionation: why aren't we what we eat? J. Archaeol. Sci. 26, 667-673.

Schoeninger, M.J., De Niro, M., 1984. Nitrogen and carbon isotopic composition of bone collagen from marine and terrestrial animals. Geochim. Cosmochim. Acta 48, 625-639.

Schoeninger, M., De Niro, M., Tauber, H., 1983. Stable nitrogen isotope ratios of bone collagen reflect marine and terrestrial components of prehistoric human diet. Science 220, 1381-1383.

Schulting, R.J., Richards, M.P., 2002. The wet, wild and the domesticated: the Mesolithic-Neolithic transition on the West coast of Scotland. Eur. J. Archaeol. 5, 147-189.

Schulting, R.J., Blockley, S.M., Bocherens, H., Drucker, D., Richards, M.P., 2008. Stable carbon and nitrogen isotope analysis on human remains from the Early Mesolithic site of La Vergne (Charente-Maritime, France). J. Archaeol. Sci. 35, $763-772$.

Schwarcz, H.P., Schoeninger, M.J., 1991. Stable isotope analyses in human nutritional ecology. Yearb. Phys. Anthropol. 34, 283-321.

Sealy, J., 2001. Body tissue chemistry and paleodiet. In: Brothwell, D.R., Pollard, A.M (Eds.), Handbook of Archaeological Sciences. Wiley, Chichester, pp. 269-279.

Van der Merwe, N.J., Vogel, J.C., 1978. ${ }^{13} \mathrm{C}$ content of human collagen as a measure of prehistoric diet in Woodland north America. Nature 276, 815-816.

Van Klinken, G.J., 1999. Bone collagen quality indicators for palaeodietary and radiocarbon measurements. J. Archaeol. Sci. 26, 687-695.

Verdasco, C.C., 1999. Estudio Geoarqueológico en los valles interiores del País Valenciano: Les Coves de Santa Maira (Castell de Castells, Alacant) y el tránsito entre el Finipleistoceno y el Holoceno. Graduate thesis. Universitat de València, València.

Vigne, J.D., 2004. Accumulations de lagomorphes et de rongeurs dans les sites mésolithiques corso-sardes: origines taphonomiques, implications anthropologiques. In: Brugal, J.P., Desse, J. (Eds.), Petits animaux et sociétés humaines. Du complément alimentaire aux ressources utilitaires, XXIX Rencontres Internationales d'Archéologie et d'Histoire d'Antibes. Éditions APDCA, Antibes, pp. 261-280.

Warinner, C., Robles García, N., Tuross, N., 2013. Maize, beans and the floral isotopic diversity of highland Oaxaca, Mexico. J. Archaeol. Sci. 40, 868-873.

Zapata, L., Cava, A., Iriarte, M.J., Barybar, J.P., de la Rua, C., 2002. Mesolithic plant use in the western Pyrenees: implications for vegetation change, use of food and human diet. In: Mason, S.L.R., Hather, J.G. (Eds.), Hunter-gatherer Archaeobotany. Perspectives from the Northern Temperate Zone. University College of London, Institute of Archaeology, London, pp. 96-107. 